\title{
Hipokalsemi Olan Hastalarda Serum Kalsiyum Düzeylerinin İyonize ve Düzeltilmiş Kalsiyum ile İlişkisi
}

\author{
Özlem DOĞAN 國 1
}

ÖZ

Amaç: Hipokalsemi hastaneye yatırılan hastalarda en sık karşılaşılan elektrolit bozukluklarından biridir. Laboratuvarlarda genellikle serum total kalsiyum ölçümü yapılmasına rağmen, kalsiyumun aktif formu iyonize kalsiyumdur (iCa). En doğru iyonize kalsiyum değerleri için; plazma total kalsiyum, total protein ve albumin konsantrasyonundaki değişiklikleri göz önüne alan düzeltmelerin yapılması gerekmektedir. Biz de çalışmamızda rutinde sıklıkla kullanılan total kalsiyum ölçümü ile tespit edilen hipokalseminin altın standart yöntem olan iyonize kalsiyum ölçümünün, düzeltilmiş kalsiyum ve iyonize kalsiyum formülleri ile arasındaki ilişkiyi görmeyi amaçladık.

Gereç ve Yöntemler: Çalışmada Ankara Üniversitesi Tıp Fakültesi Cebeci Hastanesi otomasyon sistemine kayıtlı total kalsiyumu $8 \mathrm{mg} / \mathrm{dL}$ altında aynı anda iyonize kalsiyum, total protein ve albumin sonuçları olan 422 (Kadın \%43 ve Erkek \%57) veri değerlendirildi. Düzeltilmiş kalsiyum $=$ Total Kalsiyum $+[0.8 \times(4.0-$ Albumin $)]$ ve İyonize Kalsiyum $($ Zeisler metodu $)=[(6 \times$ Total Kalsiyum $)-($ Total Protein $\times 3)] /($ Total Protein +6$)$ formülleri ile hesaplandı. Bulgular: Ölçülen total kalsiyum değerleri ile ölçülen iyonize kalsiyum ve Zeisler metodu ile hesaplanan iyonize kalsiyum sonuçları arasında korelasyon bulunamadı. Total Kalsiyum ve düzeltilmiş kalsiyum değerleri arasında korelasyon katsayısı $\mathrm{r}=0.71$, \%95 güven aralığ $10.6619-0.7545$ olarak hesaplandı $(\mathrm{p}<0.001)$. Total kalsiyumu 8 $\mathrm{mg} / \mathrm{dL}$ 'nin altında bulunan 422 sonucun 341 (\%81) tanesinin iyonize kalsiyum değerlerinin de $1 \mathrm{mmol} / \mathrm{L}$ 'nin altında olduğu gözlendi. Sadece $120(\% 28.4)$ sonucun total kalsiyum, iyonize kalsiyum, düzeltilmiş kalsiyum ve hesaplanmış iyonize kalsiyum sonuçlarının hipokalsemiyi gösterdiği bulundu.

Sonuç: Hipokalsemide, klinik açıdan asemptomatikten hayatı tehdit eden durumlara kadar büyük değişiklikler görülebilir. Total kalsiyum ölçümleri özellikle kritik hastalarda albümin konsantrasyonundan ve asit-baz dengesi bozukluklarında oluşabilecek değişikliklerden dolayı hatalı değerlendirmelere neden olabileceği için, gerekli düzeltmelerin yapılması gerekmektedir.

Anahtar Kelimeler: Hipokalsemi; total kalsiyum; iyonize kalsiyum; düzeltilmiş kalsiyum.

\section{Total Calcium Levels in Patients with Hypocalcemia Compared to Ionized Calcium and Adjusted Calcium}

\begin{abstract}
Aim: Hypocalcemia is one of the most frequently encountered electrolyte disorders in hospitalized patients. Although laboratories generally measure serum total calcium, the active form of calcium is ionized calcium (iCa). It is necessary to make adjustments considering total calcium values and changes in plasma albumin concentration, based on accurate ionized calcium values. We investigated the relation between hypocalcemia as routinely determined by total calcium measurement, and the gold standard method, ionized calcium measurement, adjusted calcium, and ionized calcium formulas.

Material and Methods: 422 patients (Female 43\%, Male 57\%) with total calcium values lower than $8 \mathrm{mg} / \mathrm{dL}$, and simultaneous ionized calcium, total protein, and albumin results recorded in the automation system of Cebeci Hospital, Faculty of Medicine, Ankara University were evaluated. Adjusted Calcium $=$ Total Calcium $+[0.8 \times(4.0-$ Albumin $)]$ and Ionized Calcium $($ Zeisler Method $)=[(6 \times$ Total Calcium $)-($ Total Protein $\times 3)] /($ Total Protein +6$)$ formulas were
\end{abstract}

1 Ankara Üniversitesi, Tıp Fakültesi, Tıbbi Biyokimya A.D., Ankara, Türkiye 
used.

Results: There was no correlation between total calcium, ionized calcium, and calculated ionized calcium results. Correlation coefficient $\mathrm{r}=0.71$ and $95 \%$ confidence interval between total calcium and adjusted calcium levels was calculated as 0.6619-0.7545 ( $<<0.001)$. Ionized calcium levels in 341 patients (81\%) were below $1 \mathrm{mmol} / \mathrm{L}$. Total calcium, ionized calcium, adjusted calcium, and calculated ionized calcium results of only 120 (28.4\%) patients suggested hypocalcemia.

Conclusion: Hypocalcemia can cause clinical outcomes greatly vary between asymptomatic to life-threatening conditions. It is required to make necessary adjustments especially in critical patients since total calcium measurements may lead to false assessments due to albumin concentration and acid-base imbalance.

Keywords: Hypocalcemia; total calcium; ionized calcium; corrected calcium.

\section{GíRiş}

Kalsiyum vücutta en yüksek miktarda bulunan elektrolitler arasında yer almaktadır. Ekstasellüler sıvıda bulunan değerliği iki olan $\left(\mathrm{Ca}^{+2}\right)$ katyondur (1). Kalsiyum vücudumuzda miyokard, iskelet ve düz kas kasılma ve gevşemesi, kan koagülasyonu, nöronal iletim, sinaptik iletim, kemik metabolizması, hormon sekresyonu, kan koagülasyonu gibi pek çok biyolojik süreçte önemli rolü olan bir iyondur (2). Kalsiyum aynı zamanda pek çok enzimin normal aktivite ile çalışabilmesi ve normal sellüler fonksiyonların sürdürülebilmesi için görev alan en önemli intrasellüler mesajcı görevini görmektedir (3). Sağlıklı bir erişkinde 1000-1300 gram kalsiyum bulunmaktadır. Kalsiyumun çok büyük bir miktarı $(>\% 99)$ kemikler ve dişlerin yapısı içerisinde fosfat ve karbonat tuzları şeklinde yer almaktadır (4).

Serum total kalsiyum konsantrasyonu yaklaşık 8.5-10.5 $\mathrm{mg} / \mathrm{dL}$ (2.1-2.6 mmol/L) dir. Plazma kalsiyumunun \%50'si iyonize halde, \%40'1 proteinlere (yaklaşık \%90'1 albumine) ve \%10'u anyonlara (fosfat, karbonat, sitrat vs.) bağlı halde bulunmaktadır (5). Hücre içinde, kalsiyumun toplam konsantrasyonu değişkenlik göstermekte ve hücre dışı sıvıdaki kadar yüksek olabilmektedir. Bununla birlikte, sitoplazmadaki iyonize kalsiyum konsantrasyonu hücre dışı sıvıdakinden en azından 1000 kat daha düşük olabilmekte ve bu değer 0.13-1.13 umol/L aralığında bulunmaktadır. Serbest iyonize kalsiyum, total kalsiyumun fizyolojik olarak en önemli bileşenidir (6,7). Matematiksel olarak hesaplanarak elde edilen total kalsiyum ölçümleri özellikle kritik hastalarda albumin konsantrasyonunda oluşabilecek değişikliklerden dolayı hatalı değerlendirmelere neden olabileceği için, iyonize kalsiyum değerinin direkt ölçümü kritik hasta bakımından önemlidir (8).

Hipokalsemi, yoğun bakım gerektiren hem dahili hem de cerrahi hastalarda en sık görülen elektrolit bozukluğudur. Hipokalsemi serum kalsiyum düzeyinin $8 \mathrm{mg} / \mathrm{dL}$ değerinin altında olması olarak tanımlanmaktadır (9). Hipokalsemi en doğru şekilde iyonize kalsiyum değerleri baz alınarak, total kalsiyum değerleri ve plazma albumin konsantrasyonundaki değişiklikleri göz önüne alan düzeltmelerin yapılmasının ardından saptanabilmektedir. Böyle bir tanımda iyonize kalsiyum değerinin 4
mg/dL'nin ya da $1 \mathrm{mmol} / \mathrm{L}$ 'nin altında olması olarak belirtilmektedir. Farklı popülasyonlarda yapılmış çeşitli sınır değerleri kullanılarak hipokalsemi prevalansı \%15 ile \%88 arasında bulunabilmektedir. Hipoalbuminemi nedeniyle ölçülen hatalı düşük kalsiyum düzeyleri, iyonize kalsiyum değerinin ölçülmesiyle ekarte edilmelidir. Hipokalsemi semptomlarının gelişmesi için eşik düzey iyi bir şekilde tanımlanmamıştır. Çeşitli veriler, serum iyonize kalsiyum konsantrasyonu 2 $\mathrm{mg} / \mathrm{dL}$ 'nin $(0.50 \mathrm{mmol} / \mathrm{L})$ altına indiğinde yaşamı tehdit edici komplikasyonların ortaya çıktığını göstermektedir (10-12).

Total kalsiyum ölçümü ucuz, basit ve kolay temin edilebilmesi nedeniyle rutinde sıklıkla kullanılmaktadır. $\mathrm{Bu}$ çalışmada hipokalsemide, sıklıkla kullanılan total kalsiyum ölçümü ile altın standart yöntem olan iyonize kalsiyum ölçümü, düzeltilmiş kalsiyum ve hesaplanmış iyonize kalsiyum düzeylerini karşılaştırmayı amaçladık.

\section{GEREÇ VE YÖNTEMLER}

Bu çalışma, Ocak 2017- Aralık 2017 tarihleri arasında Ankara Üniversitesi Tıp Fakültesi Cebeci Hastanesi laboratuvar bilgi yönetim sisteminden hipokalsemik olan hasta verileri üzerinden geriye dönük olarak yapıldı. Total kalsiyum düzeyi $8 \mathrm{mg} / \mathrm{dL}$ altında olan hastaların total protein, albumin, iyonize kalsiyum sonuçları retrospektif incelendi. Yaş ortalaması 56.8 220.54 olan 422 (Kadın 183 Erkek 239) olgunun sonuçları değerlendirildi.

Çalışma 12-796-18 karar no ile Ankara Üniversitesi Tıp Fakültesi Etik Kurulundan onay aldı. Serum total kalsiyum, total protein ve albumin düzeyleri Beckman Coulter AU 5800 otoanalizörlerinde ticari kitleri ile çalışıldı. Kalsiyum için arsenazo III metodu, albumin için bromcresol ve total protein için biüret yöntemleri kullanıldı. İyonize kalsiyum iyon-selektif elektrod metoduyla Radiometer ABL 90 cihazında ölçüldü. Düzeltilmiş kalsiyum ve iyonize kalsiyum için kullanılan formüller Tablo 1'de gösterildi.

Tablo 1. Düzeltilmiş kalsiyum ve iyonize kalsiyum formülleri

\begin{tabular}{ll}
\hline Parametre & Formül \\
\hline dCa (13) & $\mathrm{tCa}+[0.8 \times(4.0-$ Albumin $)]$ \\
\hline iCa( Zeisler) (14) & {$[(6 \times \mathrm{tCa})-($ T.Protein $\times 3)] /($ T.Protein +6$)$}
\end{tabular}

dCa: Düzeltilmiş kalsiyum (mg/dL), iCa: İyonize kalsiyum (mmol/L), tCa:Total kalsiyum ve albumin , T.Protein: Total protein $(\mathrm{g} / \mathrm{dL})$

\section{İstatistiksel Analiz}

Verilerin istatistiksel değerlendirilmesinde "SPSS for Windows 20.0" istatistik paket programı kullanıldı. Değişkenler, normallik ve varyansların homojenliği ön şartlarının kontrolü yapıldıktan sonra (Kolmogorov Smirnov ve Levene testleri) değerlendirildi. Verilerin ortalama ve standart sapma değerleri hesaplandı. İki bağımlı grup verileri değerlendirilirken ölçülen ve hesaplanan kalsiyum değerlerinin karşılaştırması Paired samples $\mathrm{t}$ test ile yapıldı. Ayrıca nicel değişkenler arasındaki ilişkiler Pearson korelasyon analiziyle elde edildi. İstatistiksel anlamlılık sınırı $\mathrm{p}<0.05$ olarak kabul edildi. 


\section{BULGULAR}

Total kalsiyum değeri $8 \mathrm{mg} / \mathrm{dL}$ 'nin altında olan 422 (Kadın \%43 ve Erkek \%57) hasta verisi incelendi. Yaş ortalaması $56.84 \pm 20.54$ olarak bulundu. Total kalsiyum, iyonize kalsiyum, total protein, albumin ve hesaplanan formüllerin ortalama ve standart sapma değerleri Tablo 2'de verildi.

Tablo 2. Total protein, albumin, ölçülen kalsiyum ve hesaplanan kalsiyum değerleri

\begin{tabular}{|c|c|}
\hline & $\begin{array}{l}\text { Ort } \pm S S \\
(n=422)\end{array}$ \\
\hline Total kalsiyum (mg/dL) & ${ }^{\#} 7.53 \pm 0.51 *$ \\
\hline İyonize kalsiyum (mmoL/L) & ${ }^{\#} 0.82 \pm 0.19 * *$ \\
\hline Total protein (g/dL) & $5.75 \pm 1.01$ \\
\hline Albumin (g/dL) & $3.13 \pm 0.59$ \\
\hline Düzeltilmiş kalsiyum (mg/dL) & $8.22 \pm 0.67$ \\
\hline İyonize kalsiyum (Zeisler) (mmol/L) & $0.60 \pm 0.13$ \\
\hline \multicolumn{2}{|c|}{$\begin{array}{l}\text { *Total kalsiyum değeri düzeltilmiş kalsiyum değerinden anlaml } \\
\text { seviyede düşük } p<0.001, * * \text { iyonize kalsiyum değeri hesaplanan iyonize } \\
\text { kalsiyum değerinden anlaml seviyede yüksek } p<0.001 \text {, Ort } \pm S S: \\
\text { Ortalama } \pm \text { Standart Sapma, }{ }^{\#} \text { Paired samples t-test kullanildl }\end{array}$} \\
\hline
\end{tabular}

Düzeltilmiş total kalsiyum değerleri ölçülen kalsiyum değerlerinden anlamlı seviyede yüksek iken $(\mathrm{p}<0.001)$, iyonize kalsiyum değerleri hesaplanan iyonize kalsiyum değerlerinden anlamlı seviyede yüksek bulundu $(\mathrm{p}<0.001)$.

422 değerin ölçülen total kalsiyum değeri $8 \mathrm{mg} / \mathrm{dL}$ 'nin altında olmasına rağmen 81 (\%19) vakada ölçülen iyonize kalsiyum düzeylerinin $1 \mathrm{mmol} / \mathrm{L}$ ve üzerinde olduğu yani normal olarak ölçüldüğü görüldü. $\mathrm{Bu} 81$ hasta sonucunun 59'unun (\%72.8) albumin düzeylerinin $3.5 \mathrm{mg} / \mathrm{dL}$ 'nin altında olduğu gözlendi. Total kalsiyum düzeyi $8 \mathrm{mg} / \mathrm{dL}$ olmasına rağmen ölçülen $\mathrm{iCa}$ düzeyi normal olan 81 hastanın hesaplanan iCa sonuçlarından sadece 2 (\%2.4) tanesi $1 \mathrm{mmol} / \mathrm{L}$ ve üzerinde idi. Bu iki hastanın total protein ve albumin düzeylerinin çok düşük olduğu tespit edildi. 81 hastanın 24'ünün (\%29.6) düzeltilmiş total kalsiyum sonucunun $8 \mathrm{mg} / \mathrm{dL}$ 'nin altında hesaplandığ1 ve bu 24 hastadan 8 tanesinin hipoalbuminemisinin olduğu tespit edildi.

Düzeltilmiş kalsiyum düzeyleri $8 \mathrm{mg} / \mathrm{dL}$ altında olan 143 (\%34) hastanın 8 hasta dışında ölçülen iCa düzeyleri ve hesaplanan iCa düzeyleri $1 \mathrm{mmol} / \mathrm{L}$ altında idi.

Sadece 120 (\%28.4) hastada total kalsiyum, iyonize kalsiyum, düzeltilmiş kalsiyum ve hesaplanmış iyonize kalsiyum sonuçlarının ortak şekilde hipokalsemiyi gösterdiği bulundu.

Korelasyon analizinde total kalsiyum ve iyonize kalsiyum arasında anlamlı bir ilişki tespit edilemedi $(\mathrm{r}=0.052$ $\mathrm{p}=0.192$ ). Ölçülen total kalsiyum ile düzeltilmiş total kalsiyum düzeyleri arasında pozitif yönde anlamlı bir ilişki tespit edildi ( $\mathrm{r}=0.71, \% 95$ güven aralığ1 0.6619$0.7545, \mathrm{p}<0.001)$. Ayrıca ölçülen iCa ve hesaplanan iCa arasında bir ilişki tespit edilemedi $(\mathrm{r}=-0.021 \mathrm{p}=0.066)$.

\section{TARTIŞMA}

Hipokalsemi, yoğun bakım gerektiren en sik elektrolit bozukluklarından biridir. Hipokalsemi, en doğru şekilde iyonize kalsiyum değerlerinin ölçülmesiyle veya total kalsiyum değerleri ve plazma albumin düzeylerindeki değişiklikleri göz önüne alan düzeltmelerin yapılmasının ardından tanınabilir.
$\mathrm{Bu}$ çalışmada daha önceki çalışmalara ilave olarak, hipokalsemi vakalarında kalsiyum ölçümünde altın standart yöntem olan iyonize kalsiyum ölçümünün, ölçülen total kalsiyum, albumin düzeltmeli kalsiyum ve hesaplanan $\mathrm{iCa}$ düzeyleri arasında herhangi bir ilişki olmadığı gözlendi.

Total kalsiyum düzeylerinin, kalsiyum düzeyinin belirlenmesi için kullanılan biyolojik olan aktif formu ve altın standart olan iyonize kalsiyum ölçümü ile doğru orantılı olduğu bilinmektedir. Ancak bazı klinik durumlarda bu varsayımın geçerliliği yoktur. Özellikle hipoalbuminemi ve hipoproteinemisi olan hastalarda iyonize kalsiyum ölçümü de yapılamıyorsa, diyagnostik yorumu iyileştirmek için total kalsiyum düzeylerinin albumin ve total protein konsantrasyonuna göre düzeltilebileceği öne sürülmektedir. Ayrıca pH'daki değişiklikler, albumine bağlı kalsiyum fraksiyonunu değiştireceğinden iyonize kalsiyum konsantrasyonunun da düzeltilerek değerlendirilmesi gerekebilir $(15,16)$. iCa ve tCa konsantrasyonlarını belirlemek için çeşitli denklemler kullanılmaktadır. Sava ve arkadaşları (17) bizim çalışmamızda olduğu gibi düzeltilmiş total kalsiyum değerini total kalsiyum değerinden, iyonize kalsiyum değerini hesaplanan iyonize kalsiyum değerinden yüksek bulmuşlardır. $\mathrm{Bu}$ durumun total protein ve albumin düzeylerindeki farkl11ıklara bağlı olarak kalsiyum-albumin bağlanma oranından kaynaklandığı düşünülmektedir. Jain ve arkadaşları (18) hemodiyaliz hastalarında rutinde kullanılan formüllerin $\mathrm{iCa}$ ile ilişkisinin zayıf olduğunu vurgulamışlar ve kendileri basit bir formül uygulamışlardır. Mir ve arkadaşları (19) hipoalbuminemik grupta ölçülen serbest kalsiyum düzeyleri ile farklı formüller ile hesaplanan serbest kalsiyum düzeyleri arasında anlamlı fark olduğunu göstermişlerdir. Özellikle durumu kritik hastalarda albumin düzeyindeki değişikliklerin kalsiyum düzeylerini değerlendirmede düzeltme gerektirdiğini vurgulamışlardır. Lian ve arkadaşları (20) total kalsiyum ölçümünün farklı formüller ile hesaplanan total kalsiyum değerlerinden daha üstün olduğunu ve pek çok klinik durumda en doğru sonucun iyonize kalsiyum ölçümü ile elde edildiğini göstermişlerdir.

Kalsiyum metabolizması açısından sıkı takip edilmesi gereken kritik hastalarda, kronik böbrek hastalığ1 olanlarda, hiperparatiroidizmde, asidemide, hemodiyaliz hastalarında formüller ile hesaplanan kalsiyum düzeylerinin ölçülen kalsiyum düzeyleriyle anlamlı seviyede ilişkili olmadığı gösterilmiştir.

Bizim çalışmamızda hipokalsemik olan hastalar rastgele seçilmiş ve ölçülen - hesaplanan total kalsiyum düzeyleri dışında anlamlı seviyede iliş̧i gözlenmemiştir. Bu durum bize kalsiyum metabolizmasını etkileyen durumlarda iyonize kalsiyum ölçülmesi gerektiğini düşündürmektedir. $\mathrm{Bu}$ formüllerin kalsiyumu etkileyen tüm parametreleri değerlendirmede yetersiz olduğu düşünülmektedir.

\section{SONUÇ}

Vücut kalsiyum dengesinin izlenmesinde ölçülen ve hesaplanan kalsiyum değerlerinin kullanılabileceği bilinmektedir. Bu noktadaki en önemli husus yanıltıc1 olabilecek hususları (albumin, protein, pH vs.) iyi bilmektir. Hipoalbuminemisi olanlarda kalsiyum 
durumunu göstermede tCa ölçümünün hipokalsemiyi göstermede daha etkili olduğu, normokalsemiyi atlayabileceği; düzeltilmiş kalsiyum ile normokalsemi daha iyi tespit edilebilirken hipokalseminin göz ard1 edilebileceği bilinmektedir. $\mathrm{Bu}$ nedenle, kalsiyum metabolizmasinı etkileyen bozukluklarda total kalsiyum ölçümü ve düzeltme formüllerine ilave olarak daha doğru değerlendirme yapabilmek için iyonize kalsiyum ölçümü yapılmalıdır. Özellikle iyonize kalsiyumun ölçülemediği durumlarda kullanılmak üzere iyonize kalsiyum hesaplama formülleri üzerinde yeni çalışmalar yapılmalı ve klinik durumu daha iyi yansıtan formüller bulunmaya çalışılmalıdır.

\section{KAYNAKLAR}

1. Moore EW. Ionised calcium in normal serum, ultra filtrates and whole blood determined by ion exchange electrodes. Journal of Clinical Investigation. 1970; 49(2): 318-34.

2. Ulusoy N, Polat C. Siv1-elektrolid dengesi bozuklukları. Yoğun Bakım Sorunları ve Tedavileri. 2. Bask1. Ankara: Türkiye Klinikleri; 2003.

3. Aydede H. Siv1 ve elektrolid dengesi. Miller Anestezi. İzmir: İzmir Güven Kitabevi; 2010.

4. Kayhan Z. Asit-baz ve sıv1-elektrolid dengesi. Klinik Anestezi. 3. Baskı. İstanbul: Logos Yayıncılık; 2004.

5. Ladenson JH, Lewis JW, Boyd JC. Failure of total calcium corrected for protein, albumin, and $\mathrm{pH}$ to correctly assess free calcium status. J Clin Endocrinol Metab. 1978; 46(6): 986-93.

6. Gunaydin B, Demirkıran O. Klinik Anestezi. 5. Bask1. İstanbul: Nobel Tip Kitapevi; 2012.

7. Wacker WE, Williams RJ. Magnesium/calcium balances and states of biological systems. Journal of Theoretical Biology. 1968; 20(1): 65-78.

8. Aguilera IM, Vaughan RS. Calcium and the anaesthetist. Anaesthesia. 2000; 55(8): 779-90.

9. Steele T, Kolamunnage DR, Downey C, Toh CH, Welters I. Assessment and clinical course of hypocalcemia in critical illness. Critical Care. 2013; 17(3): 1-10.

10. Berry EM, Gupta MM, Turner SJ, Burns RR. Variation in plasma calcium with induced changes in plasma specific gravity, total protein, and albumin. $\mathrm{Br}$ Med J. 1973; 4(5893): 640-3.

11. Clase CM, Norman GL, Beecroft ML, Churchill DN. Albumin-corrected calcium and ionized calcium in stable haemodialysis patients. Nephrol Dial Transplant. 2000; 15(11): 1841-6.

12. Gardner MD, Dryburgh FJ, Fyffe JA, Jenkins AS. Predictive value of derived calcium figures based on the measurement of ionised calcium. Ann Clin Biochem. 1981; 18(2): 106-9.

13. Payne RB, Little AJ, Williams RB, Milner JR. Interpretation of serum calcium in patients with abnormal serum proteins. Br Med J. 1973; 4(5893): 643-6.

14. Zeisler EB. Determination diffusible serum calcium. American Journal of Clinical Pathology. 1954; 24(5): 588-93.
15. Crottogins AJ, Anderson O. Plasma ionized calcium in the critically ill on total parenteral nutrition. Scand J Clin Lab. 1981; 41(1): 49-57.

16. Transhol I. On the diagnosis of so called normally calcaemic hyperthyroidism. Acta Med Scan. 1977; 202(6): 481-7.

17. Sava L, Pillai S, More U, Sontakke A. Serum Calcium measurement: Total versus free (ionized) calcium. Indian Journal of Clinical Biochemistry. 2005; 20(2): 158-61.

18. Jain A, Bhayana S, Vlasschaert M, House A. A formulae to predict corrected calcium in haemodialysis patients. Nephrol Dial Transplant. 2008; 23(9): 2884-8.

19. Mir AA, Goyal B, Datta SK, Ikkurthı S, Pal A. Comparison between calculated and measured free calcium values at different serum albumin concentrations. Journal of Laboratory Physicians. 2016; 8(2): 72-6.

20. Lian IA, Asberg A. Should total calcium be adjusted for albumin? A retrospective observational study of laboratory data from central Norway. BMJ Open. 2018; 8(4): 1-7. 